\title{
Diagnosis of Metastatic Breast Cancer to an Intraabdominal Lymph Node by Endoscopic Ultrasound
}

\author{
Joseph T. Merrill Young S. Oh \\ Division of Gastroenterology and Hepatology, Medical College of Wisconsin, \\ Milwaukee, Wisc., USA
}

\section{Key Words}

Breast cancer · Endosonography · Fine needle aspiration

\begin{abstract}
Breast cancer can present with metastatic disease initially or as a systemic relapse despite seemingly adequate initial treatment. We report a case of suspected metastatic breast cancer to an intraabdominal lymph node based on imaging, which was subsequently confirmed by tissue sampling at the time of endoscopic ultrasound (EUS). While previous studies have shown the utility of EUS in the diagnosis of metastatic breast cancer, this is the first case to our knowledge that describes the use of EUS in diagnosing recurrent breast cancer to an intraabdominal lymph node.
\end{abstract}

\section{Introduction}

It is estimated that in the United States, approximately 207,000 women were diagnosed with invasive breast cancer and approximately 40,000 women died from the disease in 2010 [1]. Between 1999 and 2005, 4-8\% of women in the United States initially diagnosed with breast cancer were found to have metastatic disease [1]. The most common sites of breast cancer metastases are to bone, liver, brain, lung, and subcutaneous tissues. We report the use of endoscopic ultrasound (EUS) in establishing the diagnosis of recurrent breast cancer to an intraabdominal lymph node.

\section{Case Report}

A 43-year-old female was diagnosed with invasive ductal carcinoma (modified Bloom-Richardson grade III, estrogen receptor negative, progesterone receptor negative, HER2/neu negative) of the left breast in 2008 by needle biopsy. She subsequently completed neoadjuvant therapy with cyclophosphamide, doxorubicin, and fluorouracil followed by an incomplete course of paclitaxel, 
which was discontinued prematurely due to neuropathy. At the time of left radical mastectomy, a $2.5 \mathrm{~cm}$ tumor with 7 out of 30 lymph nodes positive for malignancy was found (stage IIIC). Adjuvant therapy with radiation and docetaxel was subsequently completed. Computed tomography (CT) scans after adjuvant therapy were notable for an enlarging left upper lobe lung nodule concerning for metastatic disease. A subsequent positron emission tomography (PET) scan approximately 11 months after surgery demonstrated increased uptake of the pulmonary nodule seen on CT as well as in the right suprarenal region, which were both concerning for metastatic disease.

Due to the potential morbidity associated with sampling the lung nodule, EUS was requested to evaluate the intraabdominal finding on PET-CT. EUS demonstrated an isoechoic, well-defined $2.5 \mathrm{~cm}$ lymph node adjacent to the right kidney (fig. 1). Six passes were made with a 22 gauge fine needle aspiration needle under EUS guidance. The procedure duration was approximately $30 \mathrm{~min}$. The patient tolerated the procedure well without complications and was discharged home $1 \mathrm{~h}$ after the procedure. The final cytologic impression was consistent with metastatic breast cancer with a similar immunohistochemical profile to the primary tumor. The patient is now receiving adjuvant carboplatin and gemcitabine therapy.

\section{Discussion}

EUS is a well-recognized technique for staging and sampling various gastrointestinal malignancies. However, it has also been utilized for sampling ascites, the adrenal glands, as well as lymph nodes surrounding the esophagus, stomach, proximal duodenum, and rectum to aid in the diagnosis of malignancy [2-5]. While EUS has previously been shown to be useful in diagnosing metastatic breast cancer to the esophagus, mediastinum, pancreas, stomach, and peritoneum [2-4, 6-8], there have been no reports to our knowledge describing the use of EUS for diagnosing an intraabdominal lymph node recurrence of breast cancer as in this case. Since the diagnosis of metastatic breast cancer was established by EUS, the patient was able to receive adjuvant therapy without undergoing more invasive procedures to sample the concerning pulmonary nodule.

In conclusion, the use of EUS should be considered as a less invasive modality for diagnosing primary or recurrent malignancies located adjacent to the upper or lower gastrointestinal tract.

\section{Disclosure Statement}

The authors have no conflicts of interest to declare. 


\begin{tabular}{r|l|l|l} 
Case Reports in & $\begin{array}{l}\text { Case Rep Gastroenterol 2011;5:189-191 } \\
\text { DOI: 10.1159/000326957 }\end{array}$ & $\begin{array}{l}\text { Published online: } \\
\text { April 13, 2011 }\end{array}$ & $\begin{array}{l}\text { (2011 S. Karger AG, Basel } \\
\text { ISSN 1662-0631 } \\
\text { www.karger.com/crg }\end{array}$ \\
\hline
\end{tabular}

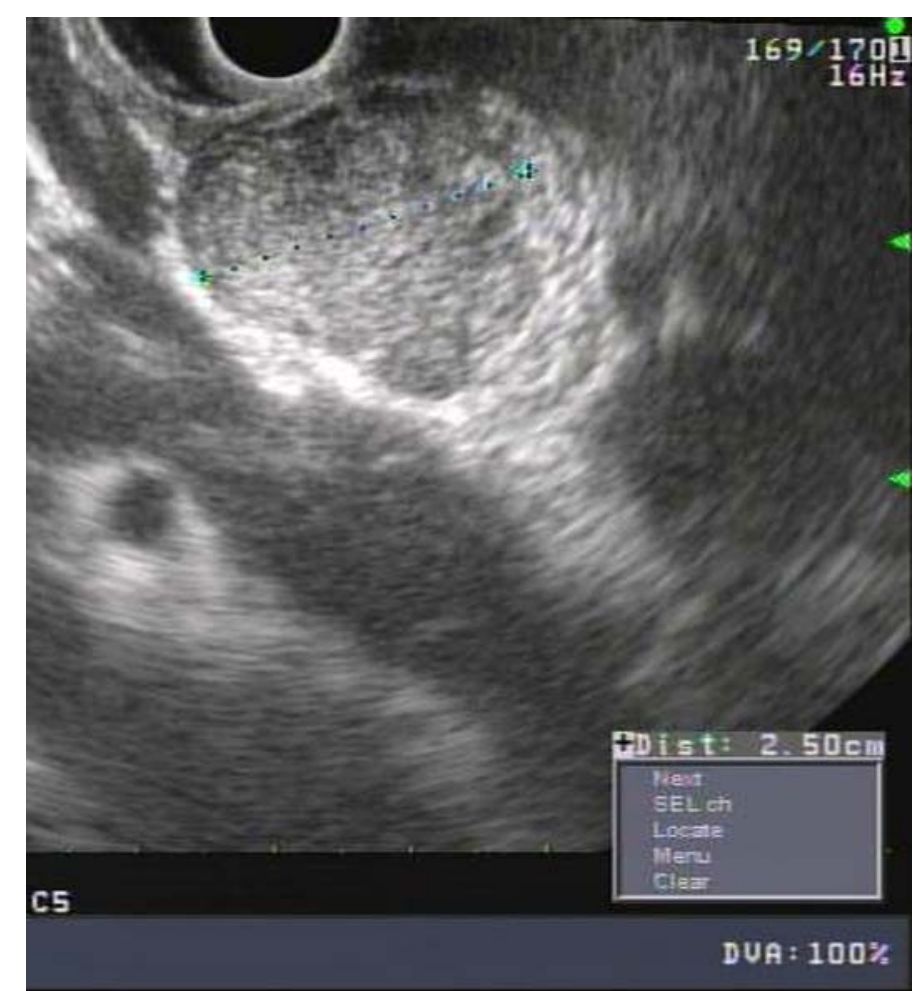

Fig. 1. EUS demonstrating an enlarged lymph node adjacent to the right kidney. Fine needle aspiration of the lymph node under EUS guidance demonstrated malignant cells consistent with a breast primary.

\section{References}

$\checkmark 1$ Jemal A, Siegel R, Xu J, Ward E: Cancer statistics, 2010. CA Cancer J Clin 2010;60:277-300.

-2 Peter S, Eltoum I, Eloubeidi MA: EUS-guided FNA of peritoneal carcinomatosis in patients with unknown primary malignancy. Gastrointest Endosc 2009;70:1266-1270.

3 Sobel JM, Lai R, Mallery S, Levy MJ, Weiersema MJ, Greenwald BD, Gunaratnam NT: The utility of EUS-guided FNA in the diagnosis of metastatic breast cancer to the esophagus and the mediastinum. Gastrointest Endosc 2005;61:416-420.

4 DeWitt J, Ghorai S, Kahi C, LeBlanc J, McHenry L, Chappo J, Cramer H, McGreevy K, Chriswell M, Sherman S: EUS-FNA of recurrent postoperative extraluminal and metastatic malignancy. Gastrointest Endosc 2003;58:542-548.

-5 Eloubeidi MA, Black KR, Tamhane A, Eltoum IA, Bryant A, Cerfolio RJ: A large single-center experience of EUS-guided FNA of the left and right adrenal glands: diagnostic utility and impact on patient management. Gastrointest Endosc 2010;71:745-753.

6 LeBlanc J, Youssef W, DeWitt J, Sherman S, Chappo J, McHenry L: Metastatic breast cancer to the gastroesophageal junction 14 years after radical mastectomy. Gastrointest Endosc 2004;59:733-736.

7 Fritscher-Ravens A, Sriram PVJ, Krause C, Atay Z, Jaeckle S, Thonke F, Brand B, Bohnacker S, Soehendra N: Detection of pancreatic metastases by EUS-guided fine-needle aspiration. Gastrointest Endosc 2001;53:65-70.

-8 Lorimier G, Binelli C, Burtin P, Maillart P, Bertrand G, Verriele V, Fondrinier E: Metastatic gastric cancer arising from breast carcinoma: endoscopic ultrasonographic aspects. Endoscopy 1998;30:800-804. 